\title{
DEVELOPMENT OF BICYCLE AND MOTORCYCLE CARRIAGE FOR GOODS MOBILITY IN
}

\section{RURAL AREAS OF NIGERIA}

Oyesiku, Olukayode Oyekanmi; ${ }^{1}$ Akinyemi, Olasunkanmi Oriola; ${ }^{2}$ Giwa, Solomon Olanrewaju.

Lawal, Nurudeen Samuel and ${ }^{3}$ Adetifa, Babatunde Olusola. ${ }^{3}$

Department of Urban and Regional Planning, Olabisi Onabanjo University, Ago-Iwoye, Nigeria

"Department of Mechanical Engineering, Olabisi Onabanjo University, Ago-Iwoye, Nigeria

'Department of Agricultural Engineering, Olabisi Onabanjo University, Ago-Iwoye, Nigeria

Corresponding author email: ooakinyemi@oouagoiwoye.edu.ng, ooakinyemi45@yahoo.com

\section{ABSTRACT}

The challenges of carrying agricultural loads and forestry products were rightly identified as essentially the rural dwellers burden. Little efforts have been made to have an adaptive mobility frame (attached to bicycle and motorcycle) to carry goods and products from the point of harvest to the point of sales (the markets), a situation that leads to systematic rot of agriculture products on the is to develop an improved carriage (trailer) to bicycle and motorcycle for goods mobility in rural are of Nigeria. The design criteria for these trailers include: lightness in weight; ease of usage; flevibility; adaptability with various bicycle and motorcycle types; low cost of engineering materials, durability and availability of materials; and it is required that the trailer carries $200 \mathrm{~kg}$ load on smooth road (tarred and untarred). Factors considered for this design include; weight of the rider, weight of bicycle and motorcycle, type of road, type of load and factor of safety. Three different trailer designs were developed for the bicycle namely fixed plate design (FPD), convertible plate design (CPD) and wire mesh design (WMD), while the motorcycle trailers developed are the fixed plate design (FPD) and the convertible plate design (CPD). The hitch system used for the WMD bicycle trailer was a conventional universal joint and collar attached to the trailer front frame and the hitch system for the and a bolt These designs are due in part to their simplicity, availability and ease of replacenous rural dwellers. Preliminary evaluations have shown satisfactory performance based on the load carrying capacity; stability of the trailer, bicycle and motorcycle turning ability; comfort of the operator and ease of disassembling the hitch system. A proper usage of the trailers presented in this study will boost the health and wealth of farmers and other rural dweller users.

Keywords: Bicycle, frame, hitch, motorcycle, trailer

Accepted Date: 25 June 2018

\section{INTRODUCTIO}

ransport refers to both motorised and nonmotorised modes used for movement of people and/or goods (e $\mathrm{g}$ bicycles, motorcycles, and It is an essential element in development and it gives the social, economic and political interaction that most people take for granted (Dinye, 2013). Transportation is a non-separable part of any ociety. It is therefore a major factor in all economic activities (Ajiboye and Afolayan, 2009). An efficient transport system offering cost, time and reliability advantage permits goods to be transported quickly (Tunde and Adeniyi, 2012).
Rural transport involves many types of movement for a wide range of purposes both within villages and beyond. The purpose of the travel may relate to the household obtaining water, fuel, and food, agricultural activities such as tending and marketing crops and livestock; or a wide variety of marketing crops and livestock; or a wide variety of socioeconomic activities which include; education,
religion, recreation, health and employment. religion, recreation, health and employment. means of transport may be appropriate depending on available infrastructure, purpose, distance, gender, and age. 
Although human carry loads of $50 \mathrm{~kg}$ for short distances, loads of $10-20 \mathrm{~kg}$ is more normal. The simple technologies such as poles, shoulder yokes or back packs. Carrying is flexible, requires little infrastructure, and is the transport means of choice for light loads and very short distances. It may be the only realistic option in difficult environment (such as those with mud, slopes, streams or dense vegetation). Simple wheeled devices such as wheel barrows, hand cart and trolleys increase human transport capacity. Depending on the environment (ground surface and slope); these can comfortably (garry 50-100 kg. Balapeed hand carts (with carty $50-100 \mathrm{~kg}$. Bals) aed he more comfort weight on the wheels) are nore comfortable than wheel barrows with one forward wheel. Wheel barrows can operate on smaller paths but need two hands to operate them. Carts, barrows and trolleys are easy to load and pack and are good for short or intermittent journeys (100-2000 meters).

In developing countries, vehicle ownership is low per capita. dependency on public transport is high but insufficient. This in own cars and mobi own cas and molking, intermediate means oftansports (IMTs) and public transport. Ahigh proportion of the poor rural peopl walk or use non-motorised transport, particularly for journeys less than 5-8 $\mathrm{km}$ (Starkey and Hine, 2014). Poor rural people often cite the need for better transport (roads and transport services) as key investments that would improve their lives (Riley and Bathiche, 2006; Odoki et al., 2008). Rural transport services are often provided by informal sector services are often provided by pickups, ' 'ural taxis' (minibuses or estate cars), picks, 'reras, ticys' (mibuses,

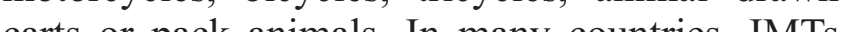
pack aninas. in many counties, IMTs (including motorcycles) provide most of the transport between villages and markets. National transport authorities tend to neglect the importance of non-motorised IMTs for poor people; however, bicycles and work animals provide crucial mobility to access markets, healthcare and schools (Oyesiku, 2016). They also provide employm opportunities, including bicycle taxi operations and bicycle repairs.

IMTs range from simple wheelbarrows and hand-

carts, to bicycle-based and motorcycle-based technologies and include 2-wheel carts or 4-whee (Riverson Stare 2002). Starkey, 2002). IMTs provide local transpor carrying people and goods around villages (and towns) and some also provide transport betwee villages and markets, either for individuals or as informal transport services. Most rural transpor services are 'mixed', with passengers and small freight, in light trucks, minibuses or buses (Starkey, 2007). On many rural roads, IMTs constitute the majority of the traffic and together they may carry large nu tors of people and significant que ( (Starkey et al., 2013). In many countries, ming the most common vehicle on rural roads.

The role of African women in porterage is remarkable: they may spend over 4 hours per day solely on transport and move approximately $50 \mathrm{~kg}$ per day (Philpott, 1994). Porter, (2002) reported from African surveys that women typically accoun for about $65 \%$ of all household time spent in for about $65 \%$ they undertake $71-96 \%$ of all domestic travel. Many women will also be carrying a baby on their back in addition to these loads. Health problems associate with head-loading may include backache, head and chest pain, deformation of the spine and osteoarthritis of the soft tissue of the knee (Porter et al. 2007). Some of the health issues may even have inter-generational impacts such as miscarriage, damage to the unborn foetus and reduced quality and quantity ofbreast milk

In most rural areas of Nigeria, bicycles an motorcycles are the most means of transportation. The bicycle is a unique type of intermediate mean of transportation that is used to transport both passengers and goods while motorcycle is a unique type of motorised transport that also transport passengers and goods. It should be noted that rura agricultural goods are mostly carried to market place by head loading and hand loading. I addition, most riders of bicycles and motorcycles usually carry goods in unsafe conditions, hence, the need to develop a trailer to be adapted to bicycl and motorcycle for goods mobility.
Cycle trailer technology was a common sense solution to carrying loads or head loading. The problem of carrying loads or head loading was (mostly women) burden and it is the main goal of this research study to propose a solution that will completely be in tune with the immediate economic, social and cultural environment of the rural dwellers in Nigeria. The main goal of this research work is to develop an improved carriage to bicycle and motorcycle for goods mobility in rural areas of Nigeria.

\section{Existing Carriage Solution}

In Nigeria, the inhabitants of rural areas are mostly farmers engaged in agriculture producing goods such as palm oil, yam, gari, kola nut, rice, beans, cocoa, etc.; that are consumed in the cities and most

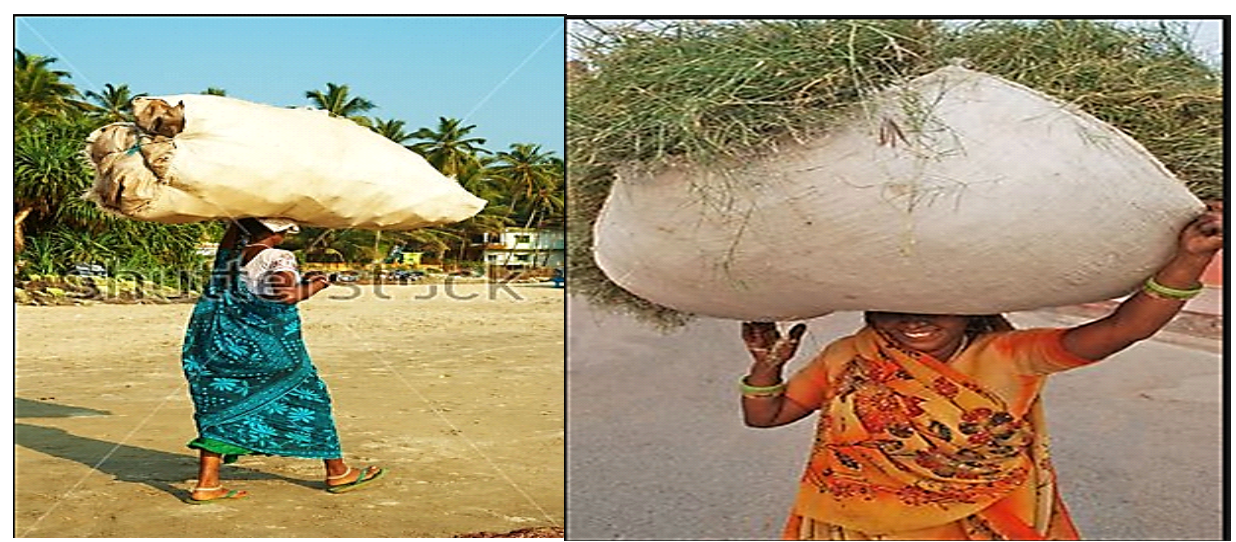

Figure 1: Head loading of agricultural product

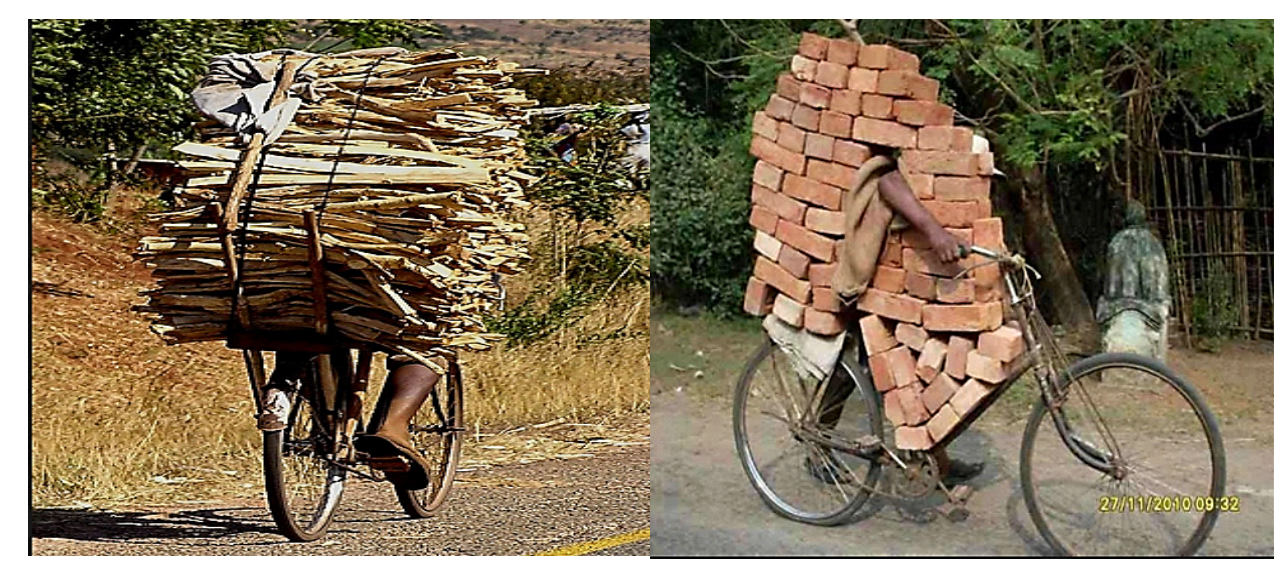

Figure 2: Loading of bicycles 


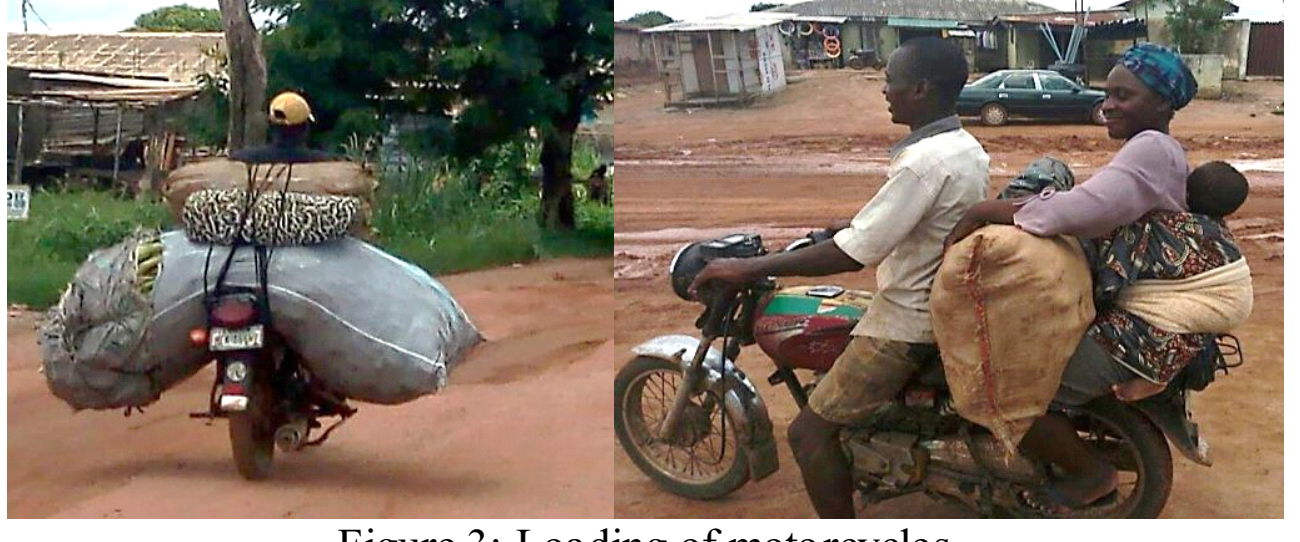

Figure 3: Loading of motorcycles

In many Asian countries, non-motorised bicycles (two wheelers) and three wheelers are common sights, employing special adaptations to the vehicles for goods transport, hawking or taking passengers. Bicycle trailers were developed by Practical Action (a non-governmenta organisation) in Sri Lanka and then adopted by Practical Action East Africa (Kenya) and now in Nepal and Zimbabwe (Michael, 1986). Practical Action has worked on a range of transport technologies that address different transport needs, such as Ox carts, extended load carrying such ax carts, extended lo carrying bicycle, aerial runways, bicycle taxis, bicycle ambulances, wheelbarrows, low cost wheel making, anima harness, low cost road construction and bicycle

Bicycle trailers are used for transporting goods, fuel, water and harvested products where other means are expensive. Trailers allow people carry three times as much as with a bicycle which allows people carry load in an unsafe manner (Michael, 1986). It has been used for mobile store and kitchen and mobile library for school children both in Sri Lanka. It has also been used for an ambulance (figure 4). Cycle trailer was reported as a reasonable but inappropriate technology (Mohammed, 1997). This was due to the resulted in the trailer collapse. Furthermore, the technology failed to win popular recognition because it was unaffordable and not entirely relevant to the needs of its intended users.

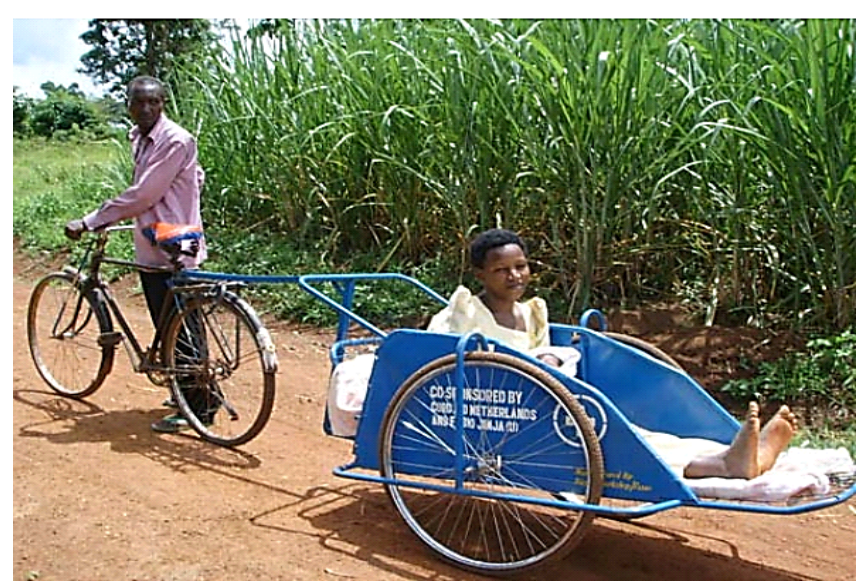

Figure 4: Bicycle ambulance (Wallrap and Faust, 2008)

Many of the bicycle complements are multiple-use as well, and are marked as such. However, conditions in many developing countries require bicycles that can safely transport people and heavy cargo over unpaved roads. Bicycles, because of their light weight, put less wear and tear on roads than motorised vehicles, and this translates into lower road maintenance and repair costs. Another advantage is the zero emission level which is mostly encouraged globally. In addition, motorcycles have become a major means of transporting goods and humans in rural areas in hich Nigeria is not an exception. Attachment of movement of mostly agricultural products.
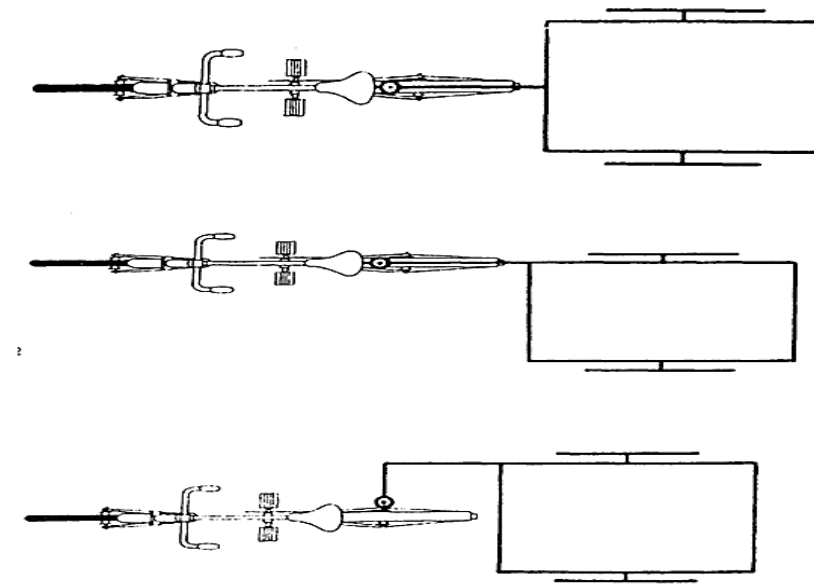

Figure 5: Configurations of bicycle trailer designs (Ayre, 1986)

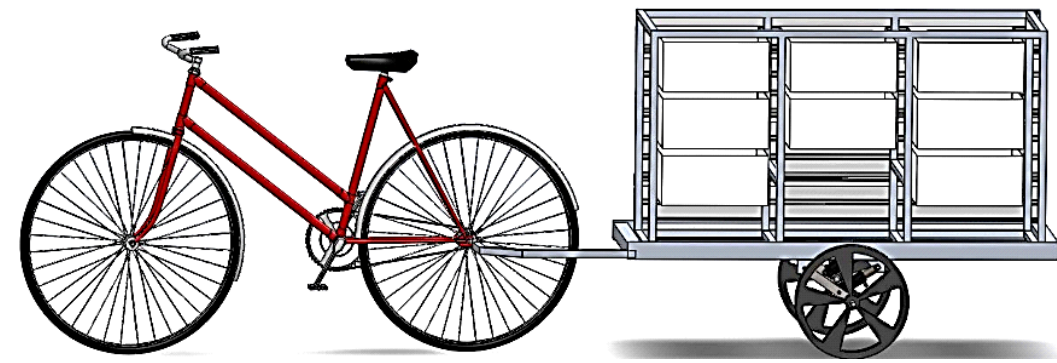

Figure 6: Bicycle trailer designed for Higher Ground Farms (Hastings et al, 2016) 


\section{Materials and Method}

Three different trailers were developed for bicycles while two trailers were developed for the motorcycles. For bicycles, there was a fixed plate design (FPD), convertible plate design (CPD) and wire mesh design (WMD), while the motorcycle trailers developed are the fixed plate design (FPD) and the convertible plate design (CPD). These improved trailers were expected to be light in weight; easy to use; flexible; adaptable with various bicycle and motorcycle types; made of low cost, durable and locally available materials; and able to carry load of 100-200 kg on untarred and coste durable and locally avalable materials; and (the , Mot $\mathrm{m}$; Motorcycle front wheel dianeter dfw $-0.57 \mathrm{~m}$; Motorcycle rear wheel diameter drw $-0.58 \mathrm{~m}$; Bending stress of mild steel $(\sigma b)-155 \times 10^{6} \mathrm{~N} / \mathrm{m}^{2}$ Shear stress of mild steel $(\mathrm{Ss})-40 \times 10^{6} \mathrm{~N} / \mathrm{m}^{2}$

\section{Design}

Trailer Capacity

In determining the trailer capacity, it was assumed that the length and width will accommodate two 50 kg jute bags each.

Width of trailer: Since the width of a $50 \mathrm{~kg}$ jute bag is $0.4 \mathrm{~m}$, it implies that a width of $0.8 \mathrm{~m}$ will be adequate for the trailer

2. Length of trailer: The length of a $50 \mathrm{~kg}$ jute bag is $0.8 \mathrm{~m}$; hence, a trailer length of $1.6 \mathrm{~m}$ will be adequate for two $50 \mathrm{~kg}$ jute bags.

3. Height of trailer: The depth of a $50 \mathrm{~kg}$ jute bag is $0.2 \mathrm{~m}$; will be adequate for two $50 \mathrm{~kg}$ jute bags.

\section{Trailer Chassis}

The design load will be carried by the base of the trailer. The base was divided into 8 sections. For ease of construction, the members of the base of the chassis are of the same dimension (i.e. $0.4 \mathrm{~m}$ long). In determining the dimension of the hollow mild steel and angle iron which will sustain the design load, it was assumed that the design load will act as a point load equally shared on 4 members of the frame. The bending moment was estimated from equation 1

Maximum bending moment $\left(\mathrm{M}_{\max }\right)=\frac{\mathrm{W}_{\mathrm{l}} \mathrm{L}}{8}$ (1)
With an external weight $(\mathrm{Wl})$ of $100 \mathrm{~kg}$ per member and a length (L) of $0.4 \mathrm{~m}$, the maximum bending $91 \mathrm{Nm}$. Using equation 2 below, this will give a sectional modulus of $0.316 \mathrm{~cm} 3$.

Ė I I Î́ŇŃï $Ł$ modulus $(\mathrm{z})=\frac{\mathrm{M}_{\max }}{\sigma_{\mathrm{b}}}$

Based on this, angle iron $(2 \times 2 \times 1.5 \mathrm{~mm})$ and hollow square pipe $(1.5 \mathrm{~mm})$ were selected. Thi selection will also cater for the bending momen due to the self-weight of the members.

Equation 3 was further used to check for failure due to vertical shear stress of component parts.

Vertical shear stress $\left(\sigma_{\mathrm{v}}\right)=\frac{\mathrm{W}_{1}}{\mathrm{~A}}$

The values of $\sigma_{v}$ were found to be lesser than $\sigma_{\mathrm{s}}$ which implies that the selected section will not fail under vertical stress.

\section{Trailer Wheel}

The technical considerations for wheels of bicycle and motorcycle trailer will depend on the weight to be carried and the conditions of the road. In addition, the trailer wheels must be capable of carrying a loac friction bearing in the hubs.

In other to sustain the design load, the rear wheel of a motor cycle was selected for the FPD and CPD trailers for the bicycle and motorcycle. For the two designs, the wheel will have the following specifications; external diameter of $584.2 \mathrm{~mm}$, rim diameter of $431.8 \mathrm{~mm}$, thickness of $7.62 \mathrm{~mm}$ and pressure: 36 psi. For WMD bicycle trailer, the wheel selected was a Raleigh bicycle wheel

\section{Shaft forTrailer Wheel}

A major requirement for a two wheel bicycle and motorcycle trailer is that the wheels must rotat independently of each other. To achieve this, slotted plates and the rear shaft of a motorcycle wheel were selected for the FPD and CPD trailers for bicycle and motorcycle. The shaft for a Raleigh bicycle wheel was used for the WMD bicycle trailer. The slotted plates allow each wheel to be removed shats used for the trailers were around $17 \mathrm{~cm}$ long. The shafts will be subjected to bending moment only. For a round shaft, the diameter is given by equation 4 .

$$
\mathrm{d}=\sqrt[s]{\frac{32 \mathrm{M}}{\pi \sigma_{\mathrm{b}}}}
$$

Where; $\mathrm{M}$ is the bending moment due to the load on the shaft 7 shows the free body diagram, (Mear force (Qy) diagram and bending monent $\mathrm{Mx}$ ) diagram of the shaft. From figure 7 , the total

\section{Scheme of Beam:}

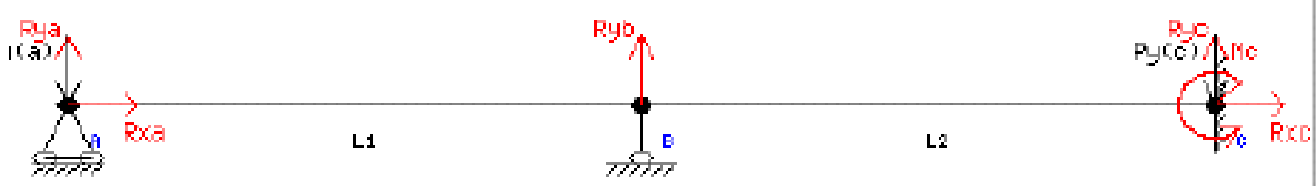

Curve 0 :
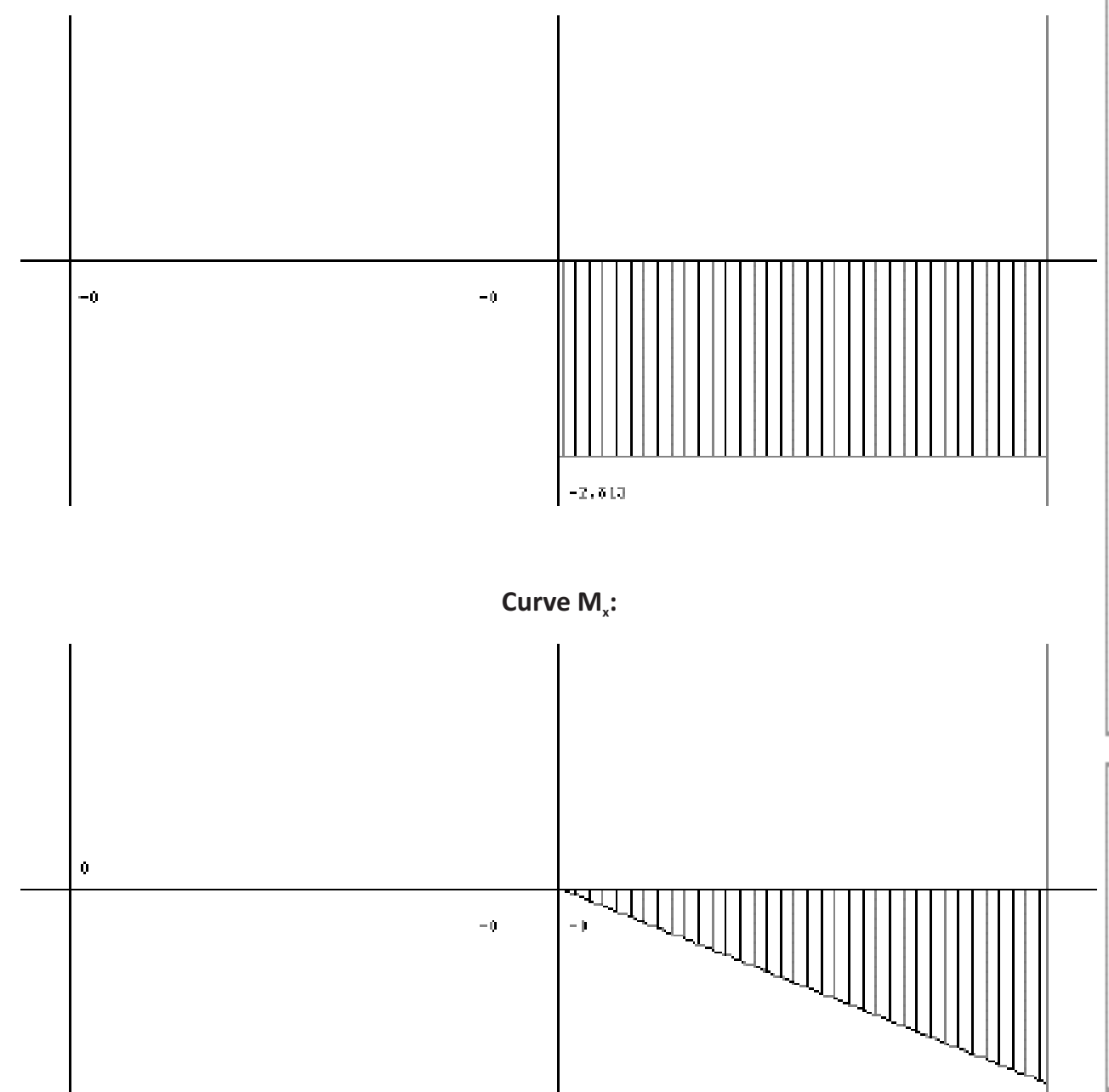

Figure 7: Shaft analysis

Using a bending moment of $0.239 \mathrm{KNm}$ in equation 4 , a shaft diameter of $25 \mathrm{~mm}$ is appropriate. load to be carried by the shaft is a point load of trailer and the load to be carried by each wheel. This load will give rise to different reactions at the supports. The maximum shear force on the shaft is $2.813 \mathrm{kN}$ (figure 7), while that the maximum bending moment on the shaft is $0.239 \mathrm{kNm}$.
Nubmer of polnts: 3

Lengths of the beam
$L 1=0.085(\mathrm{~m})$ $\begin{aligned} 11 & =0.025(\mathrm{~m}) \\ 12 & =0.085(\mathrm{~m})\end{aligned}$

supports:

Polnt - B-

Umber of reactions of supports on the Y-ax) -4
on the $X-2 x \mid 5-2$

The system on the vertical $Y-a x$

The system on the hortzontal $x-$-xxls:

stems in the Z-2xis (the rotatucion (shaft) Concentrated forces (along $\mathrm{Y}$ axls): $\mathrm{Py}(\mathrm{a})=-1.125(\mathrm{kNN})$
$\mathrm{Py}(\mathrm{c})=-1.125(\mathrm{kN})$

concentrated forces (along $\mathrm{X}$ axss):

ending moment:

Torques

Stributed forces (along Y axls:

solution

(n)

$\mathrm{RY} \mathrm{y}_{\mathrm{a}}=1.125(\mathrm{kN})$
$\mathrm{RY}=-2.813(\mathrm{kN})$

$\mathrm{n} Y \mathrm{y}=2013(\mathrm{kN})$

$\mathrm{Mc}=-0.048(\mathrm{kN})$

Cy $\mathrm{M}_{\max }=2.813(\mathrm{kN})$

P-ISSN 2536-6904 African Journal of Science \& Nature Vol.6, 114-130(2018) 


\subsubsection{Hitch System}

The hitch system comprises; the hitch (between the trailer and the cycle), the hitch mount (on the bicycle and the motorcycle) and the hitch support frame (attachment to the trailer chassis or plate). The hitch system used for the WMD bicycle trailer was a conventional universal joint and collar

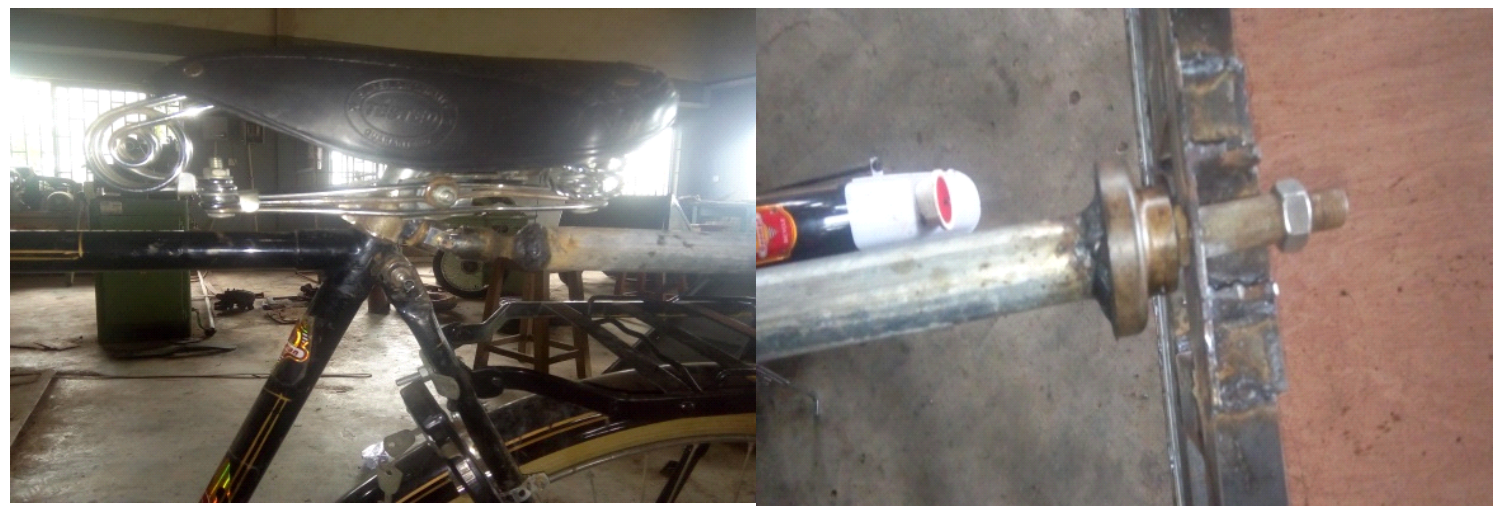

Figure 8: Hitching system for bicycle WMD trailer

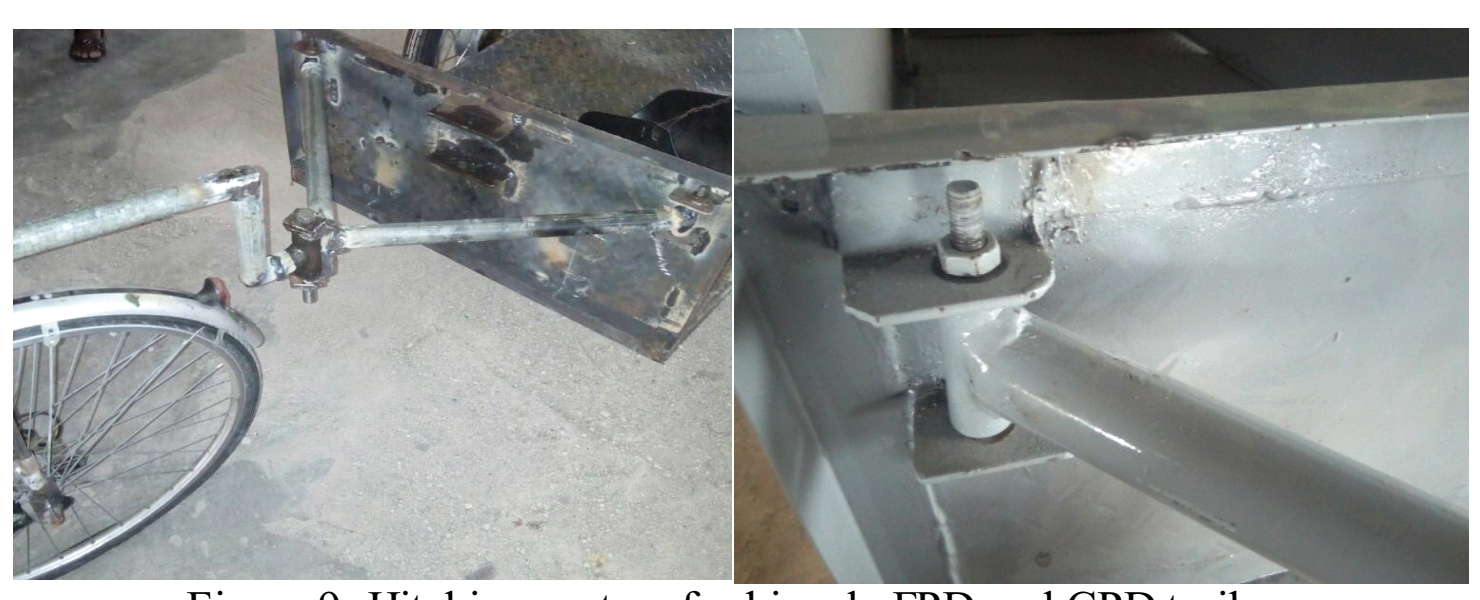

Figure 9: Hitching system for bicycle FPD and CPD trailers

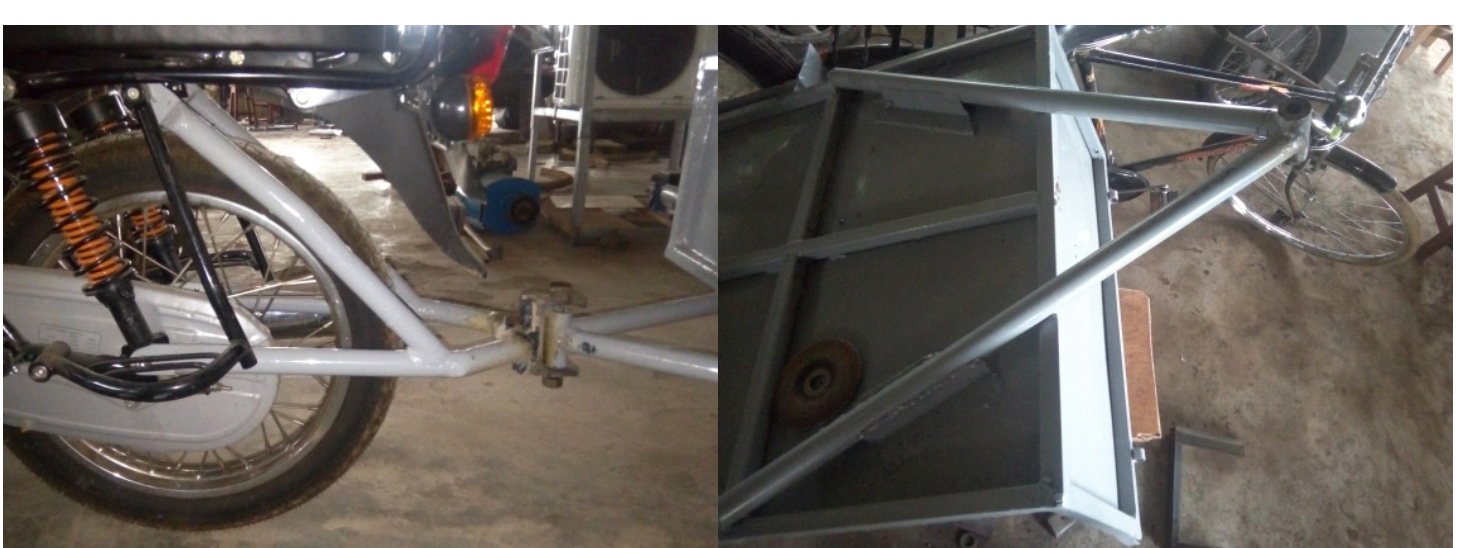

Figure 10: Hitching system for motorcycle FPD and CPD trailers

\section{Fabrication}

Figure 11 summarizes the fabrication processes which are: gathering of materials, fabrication of chassis base, fabrication of chassis wall, covering chassis with metal plates, installation of wheel shaft, installation of wheels, installation of wheel mud guard, installation of hitching point,
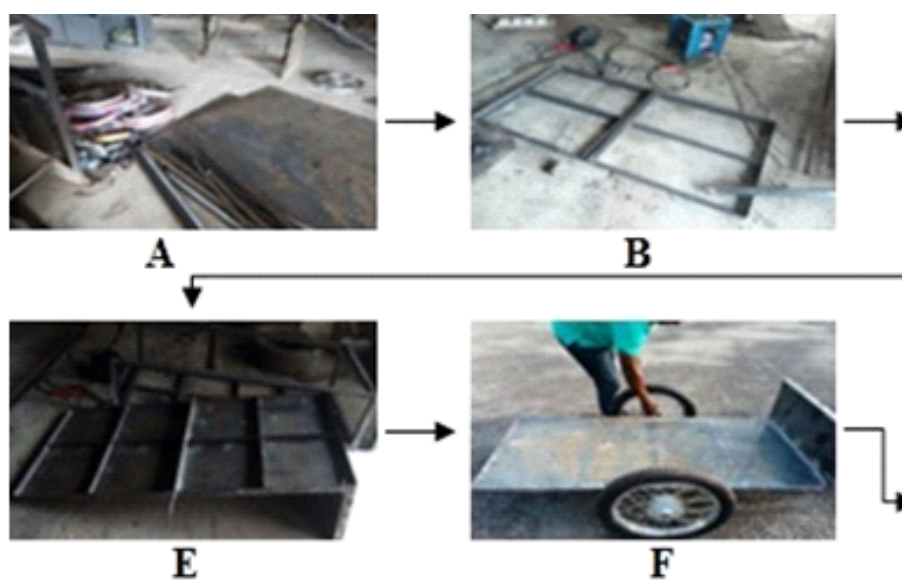

fabrication and installation of hitch, painting and motorcycle The summary of the components along with the materials used is as presented in Table 1 .
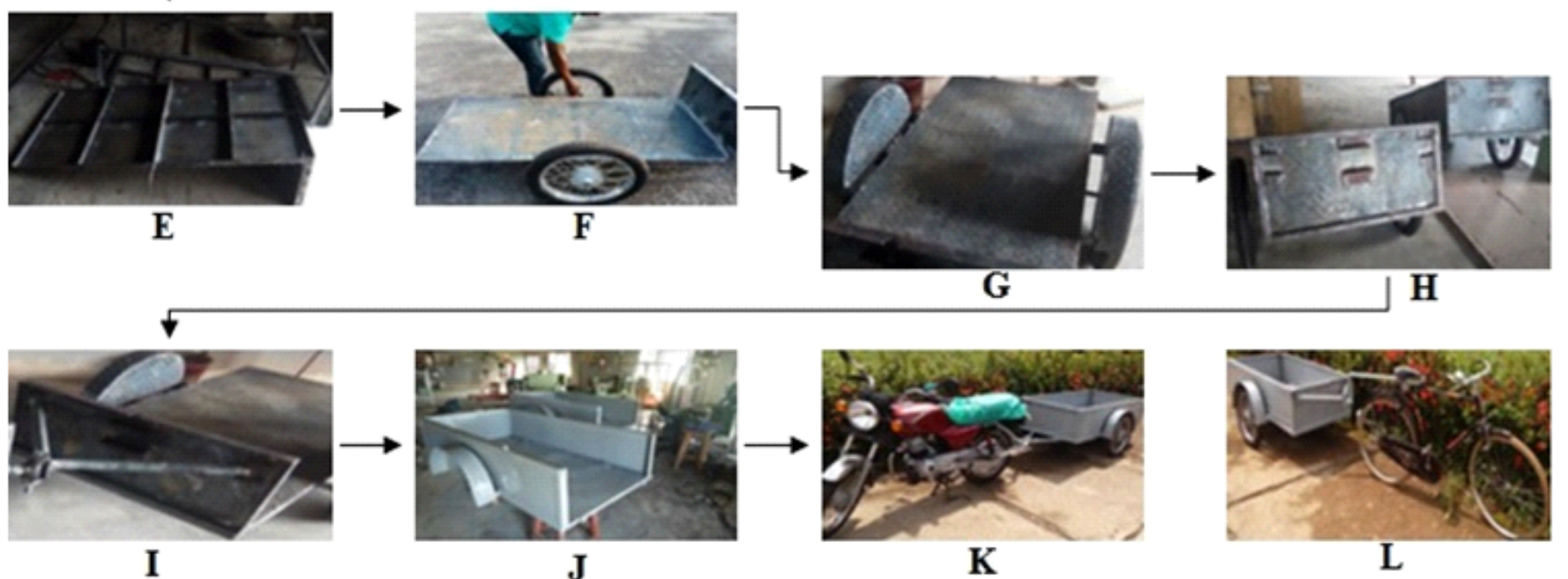

Figure 11: Fabrication process (Key: A - Gathering materials; B \& C - Chassis fabrication; D - Fixing plates (or wire mesh); EInstalling Wheel shaft; $\mathrm{F}$ - Installing wheels; $\mathrm{G}$ - Fixing wheel mud guard; $\mathrm{H}$-Adding hitch point; I-Adding Hitch; J - Painting \& K/L: Mounting on cycles).
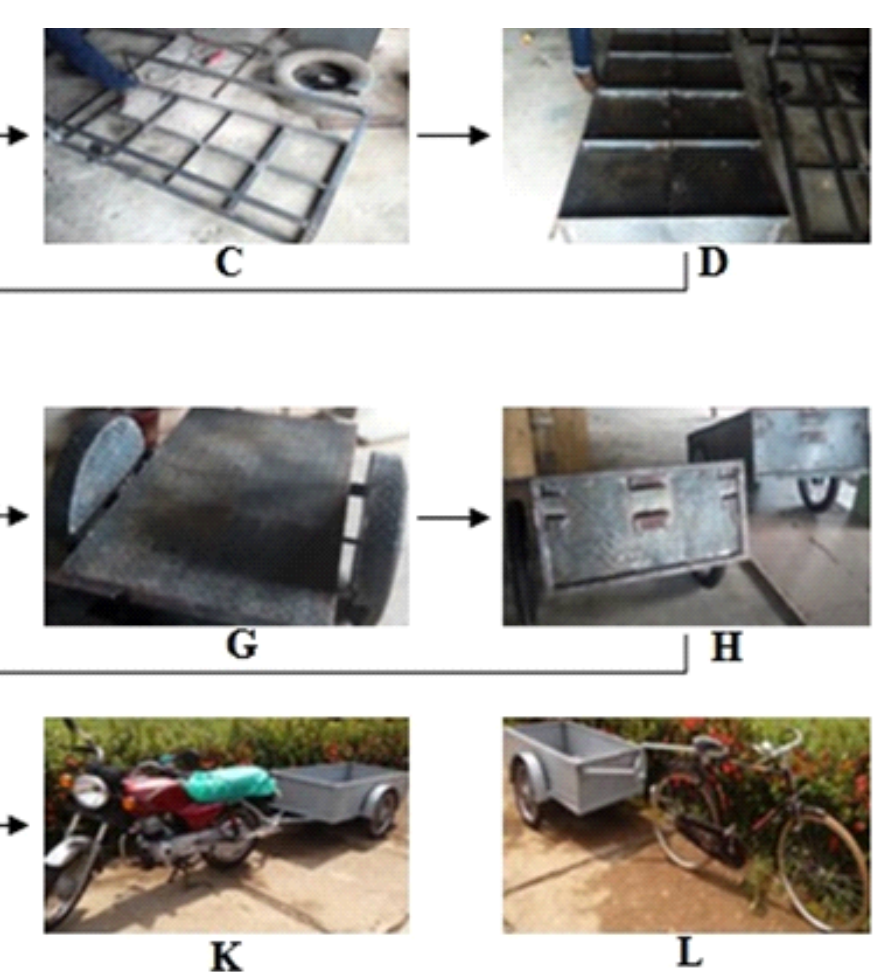

\begin{abstract}
-
\end{abstract}
IJSN P-ISSN 2536-6904 African Journal of Science \& Nature Vol.6, 114-130(2018) 
Table 1: Components of trailers

\begin{tabular}{lll}
\hline $\mathbf{S} / \mathbf{N}$ Components & Bicycle Trailer & Motorcycle Trailer
\end{tabular}

1. Chassis

Angle iron $(2 \times 2 \times 1.5 \mathrm{~mm})$ and $\quad$ Hollow square pipe $(1.5 \mathrm{~mm})$ $(1.5 \times 1.5 \times 1.5 \mathrm{~mm})$

2. Base plate ${ }^{\mathrm{FP} \& C P D}$ Standard chequered mild steel

Standard chequered mild steel plate $(2 \mathrm{~mm})$

plate $(2 \mathrm{~mm})$

Base plate WMD Wire mesh and plywood N/A

3. Side plate ${ }^{\mathrm{WMD}}$ Wire mesh

\section{$\mathrm{N} / \mathrm{A}$}

Side plate ${ }^{\mathrm{FPD}}$

Standard chequered mild steel

Standard chequered mild steel plate $(2 \mathrm{~mm})$

Side plate ${ }^{\mathrm{CPD}} \quad$ Aluminium plate $(1.5 \mathrm{~mm})$

4. Shaft Motorcycle rear shaft

5. Wheel ${ }^{\text {FPD\&CPD }}$

Motorcycle rear wheel

Aluminium plate $(1.5 \mathrm{~mm})$

Motorcycle rear shaft

Motorcycle rear wheel

Wheel ${ }^{\text {WMD }}$

Raleigh bicycle wheel

$\mathrm{N} / \mathrm{A}$

6. Hitch point o Two hitch point at the front side of the trailer

Welded to the chassis of the trailer

7. Hitch support Hollow mild steel pipe $(25 \times 25$ $\times 2.6 \mathrm{~mm})$ $25 \times 2.6 \mathrm{~mm}$ )

frame

Mild steel stock (Universal Hardened steel cylinder mated joint), mild steel strip, nut(s) and with a heavy duty bolt bolt(s)

9. Hitch point on

Bolted beneath the seat

Attached to the rear wheel

cycle

10. Paint

Ash colour gloss (auto-base

paint)

Ash colour gloss (auto-base

paint)

Key: FPD - Fixed plate design; CPD - Convertible plate design and WMD - Wire mesh design

\section{Performance Evaluation}

In addition to this, preliminary field tests were carried out. This test was aimed at investigating the stability and turning ability of the entire design; the comfort ability of the operator and the ease of dissembling the hitch. The speed of the cycles was also observed for a distance of $250 \mathrm{~m}$. the motorcycle was at its lowest gear during this evaluation.

Results and Discussions

Maximum load

2. Africtionless support

3. Acceleration due to gravity

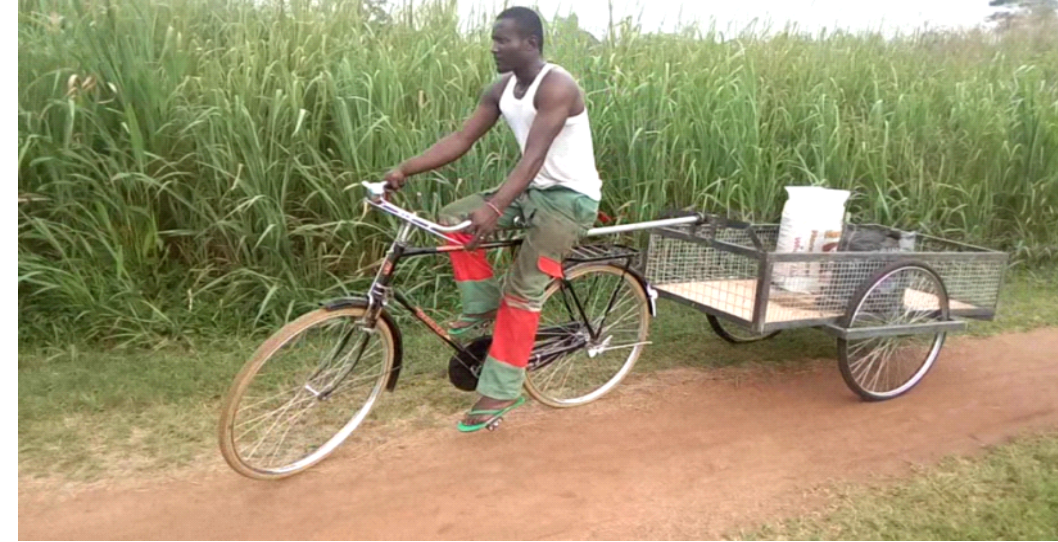

Figure 12: WMD bicycle trailer in use

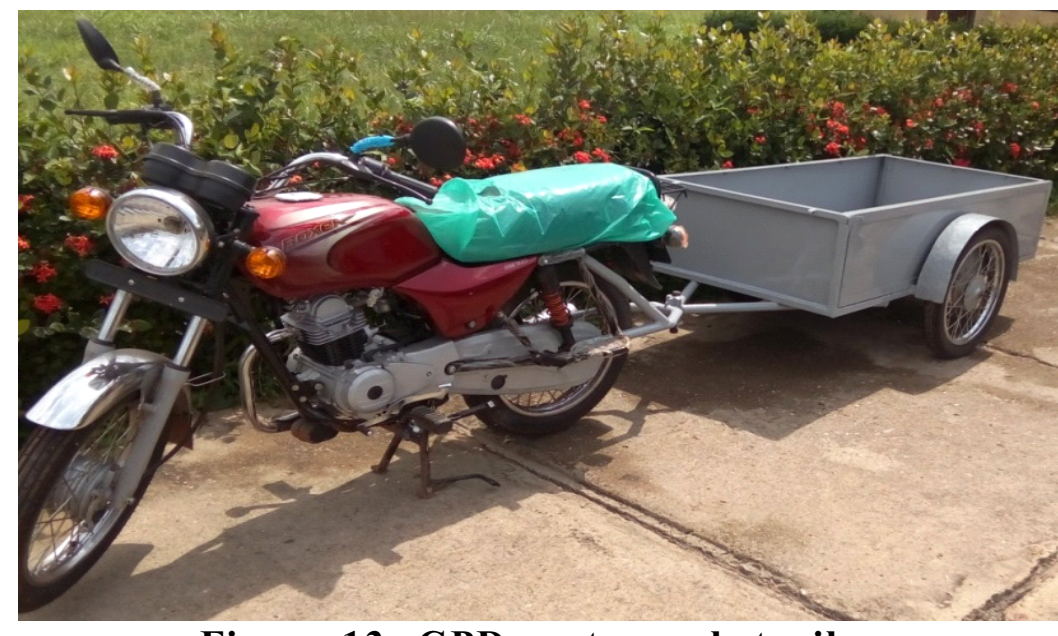

Figure 13: CPD motorcycle trailer

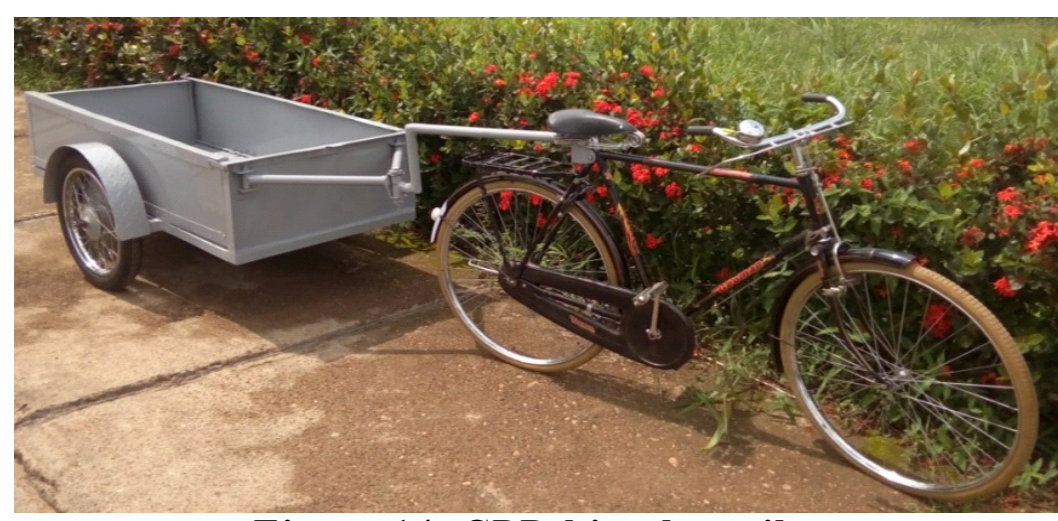

Figure 14: CPD bicycle trailer 


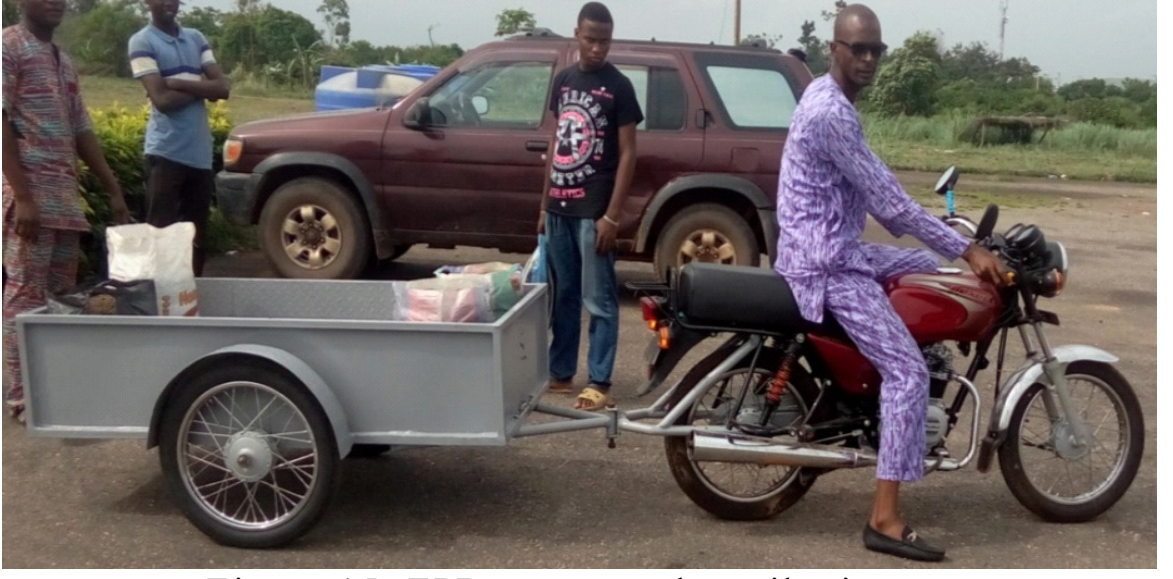

Figure 15: FPD motorcycle trailer in use

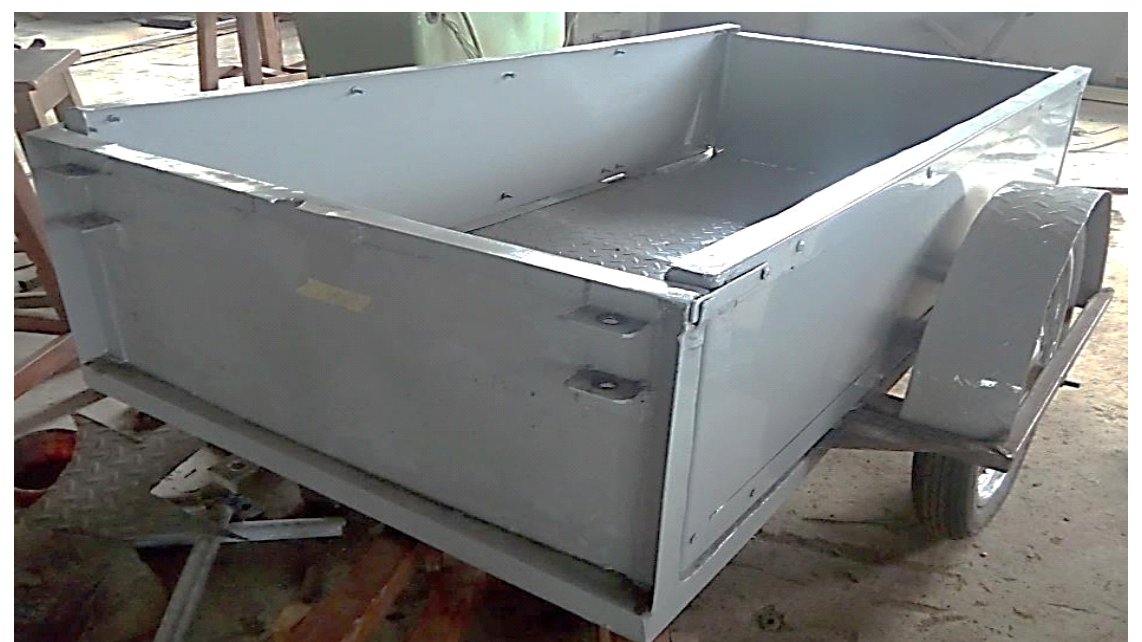

Figure 16: Un-mounted CPD bicycle trailer showing two hitching points

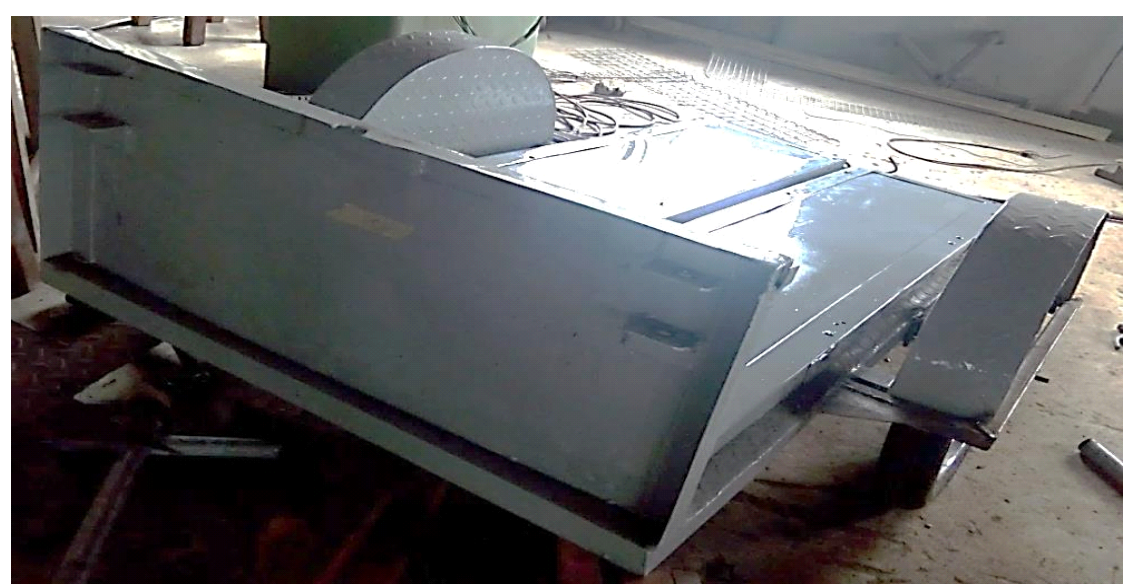

Figure 17: Un-mounted CPD bic ycle trailer (collapsed) show ing two hitching points

A P-ISSN 2536-6904 African Journal of Science \& Nature Vol.6, 114-130(2018)

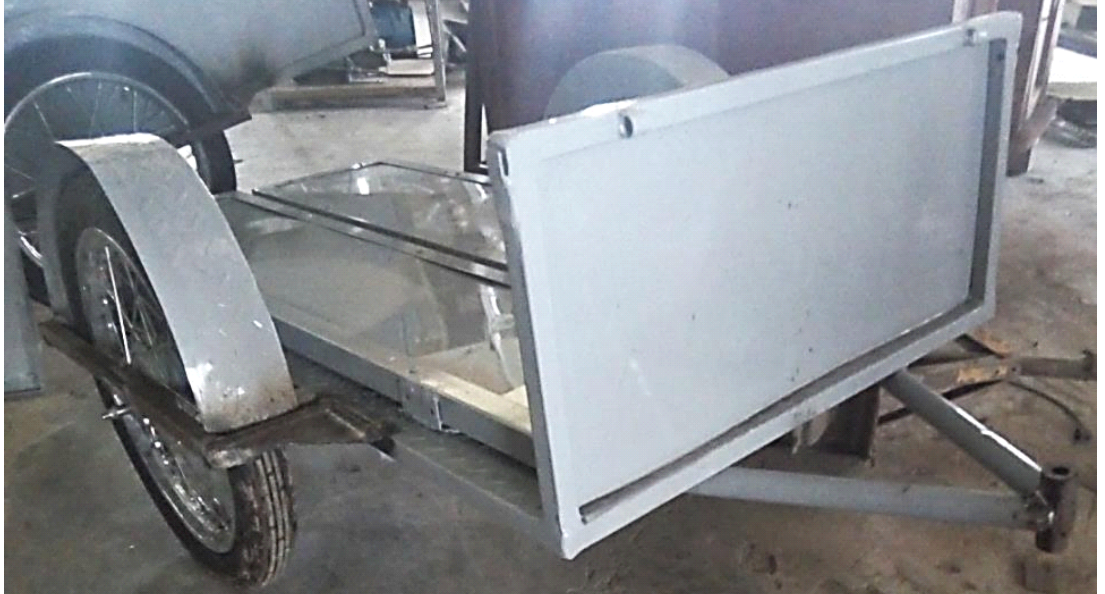

Figure 18: Un-mounted CPD motorcycle trailer (collapsed) showing the hitching point

\section{Static Structural Analysis of Trailer Chassis}

Figure 19 and 20 shows the result of the static structural analysis of the trailer chassis. Figure 16 shows that a maximum stress of $2.95 \times 106 \mathrm{~Pa}$

occurred at the joints; while figure 17 reveals the different strains on the member. The maximum strain was observed to be $8.22 \times 10-6 \mathrm{~mm}$

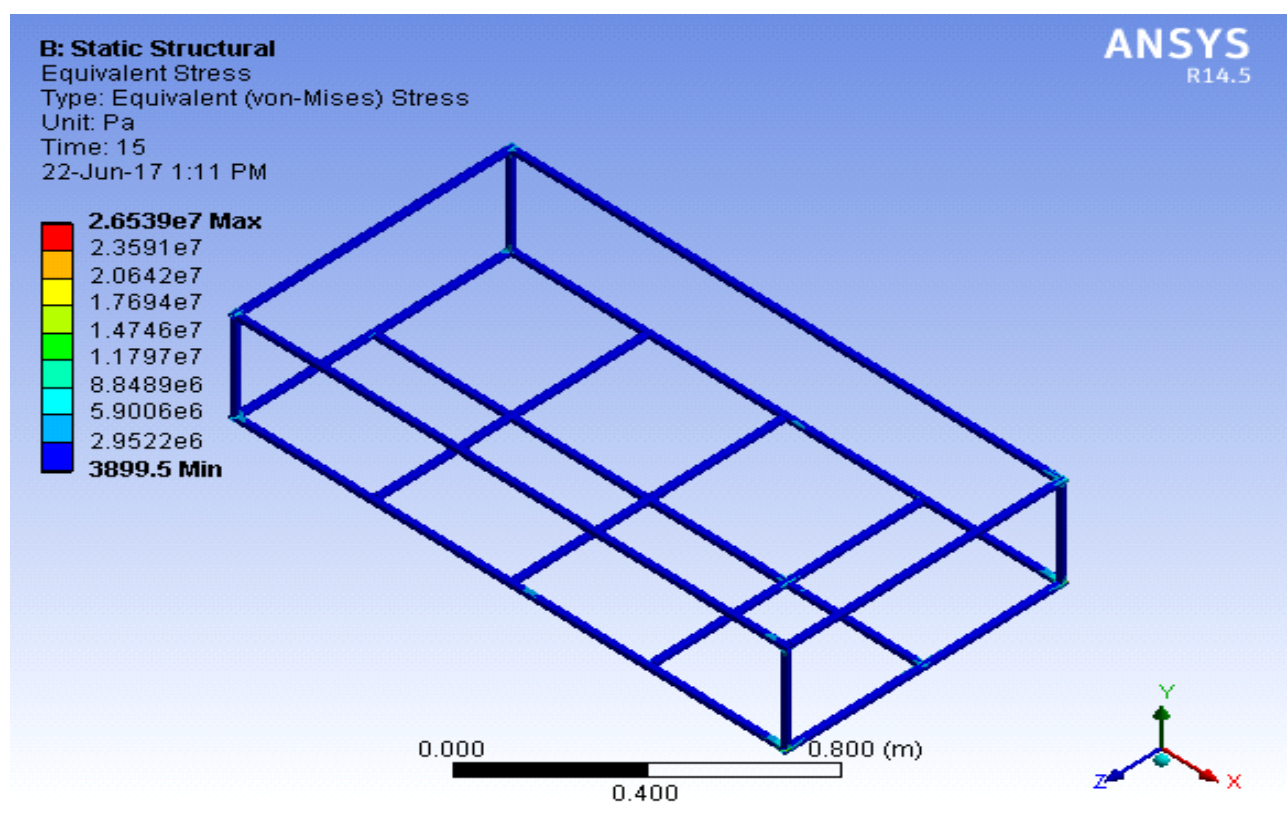

Figure 19: Equivalent stress of trailer chassis 


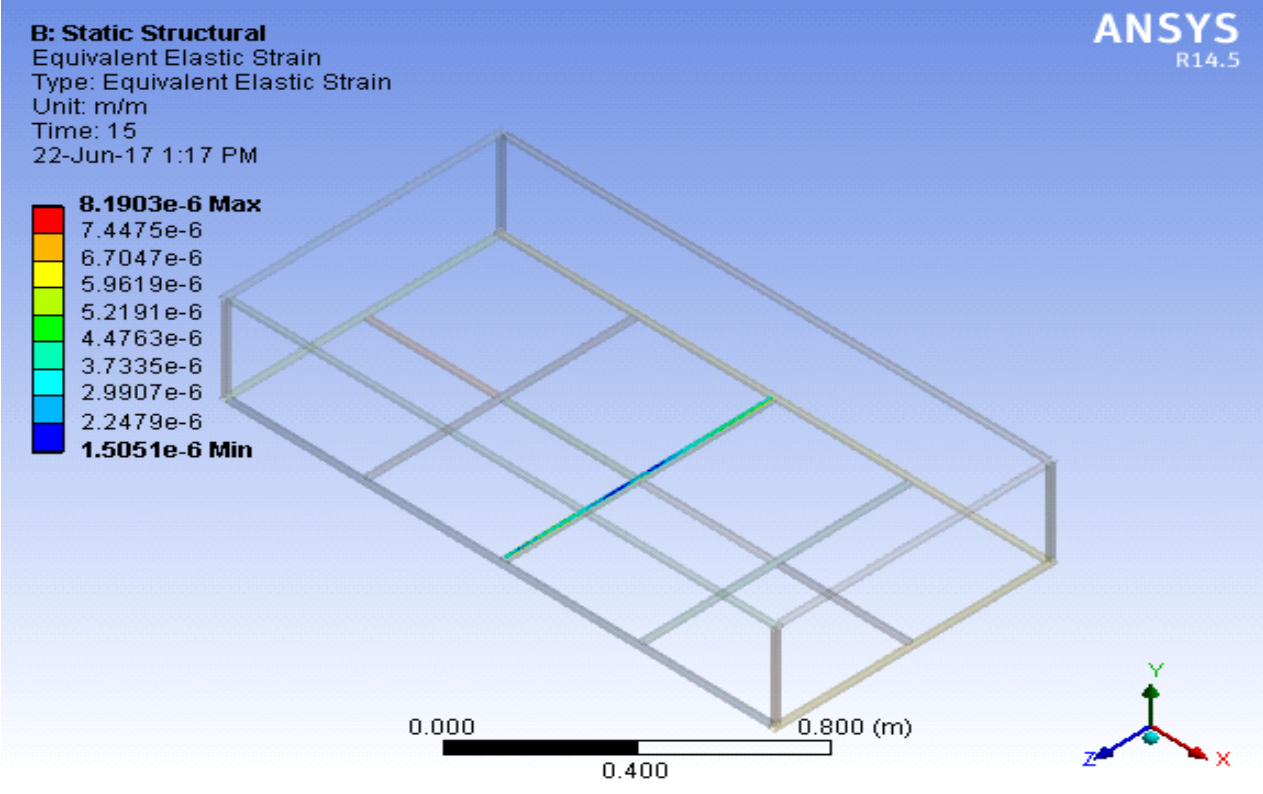

Figure 20: Equivalent strain of trailer chassis

\section{Challenges}

The major challenge encountered was developing a simple and workable hitching system. The initial design proposed a single point hitch system which was fabricated (figure 21a).This design had poor turning ability and stability. A readjustment (figure 21b) was done for the bicycle trailer; by changing the hitch point on the trailer to

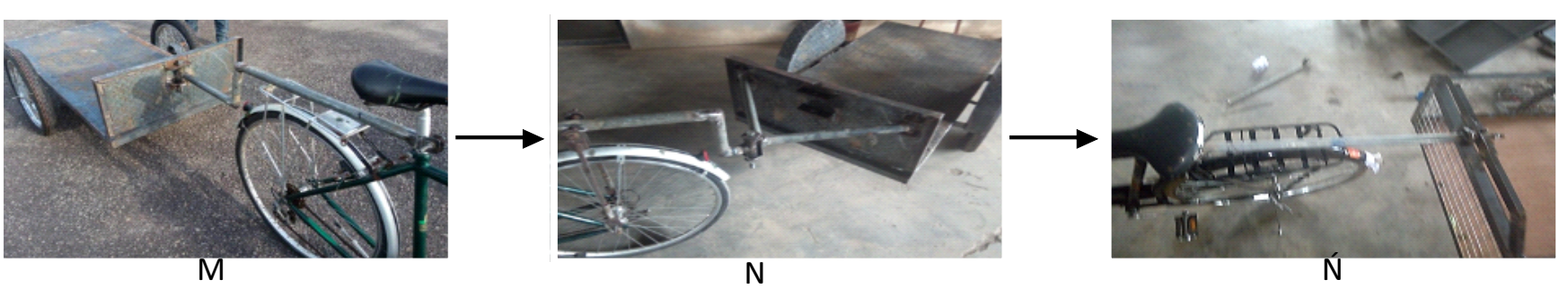

Figure 21: Read justment of hitching system

\section{Preliminary Evaluation}

Preliminary evaluation have shown satisfactory performance based on the load carrying capacity; stability of the trailer, bicycle and motorcycle; turning ability; comfort of the operator and ease of is disassem observed all through. Figures 22 and 23 shows the average speed of the trailers when mounted on a motorcycle and bicycle, respectively. At no load, the motorcycle trailer had a stable speed of $8-10$

$\mathrm{km} / \mathrm{hr}$ and $7-8.5 \mathrm{~km} / \mathrm{hr}$ at full load. The no load speed of the bicycle trailer was less than $6 \mathrm{~km} / \mathrm{h}$ while at $100 \mathrm{~kg}$ load, the speed was less than 5 $\mathrm{km} / \mathrm{hr}$. From figure 24, the WMD bicycle traile attained a higher and a more stable speed of $(5.2$ $6.3 \mathrm{~km} / \mathrm{hr}$ at no $\mathrm{load}$ and $4.9-5.6 \mathrm{~km} / \mathrm{hr}$ at $100 \mathrm{~kg}$ $6.3 \mathrm{~km} / \mathrm{hr}$ at no load and $4.9-5.6 \mathrm{~km} / \mathrm{hr}$ at $100 \mathrm{~kg}$ ) compared to the FPD/CPD bicycle trailers $(5.0$ $5.4 \mathrm{~km} / \mathrm{hr}$ at no load and $3.8-4.2 \mathrm{~km} / \mathrm{hr}$ at $100 \mathrm{~kg}$ ) This was specifically due to the light weight of the WMD bicycle trailer.

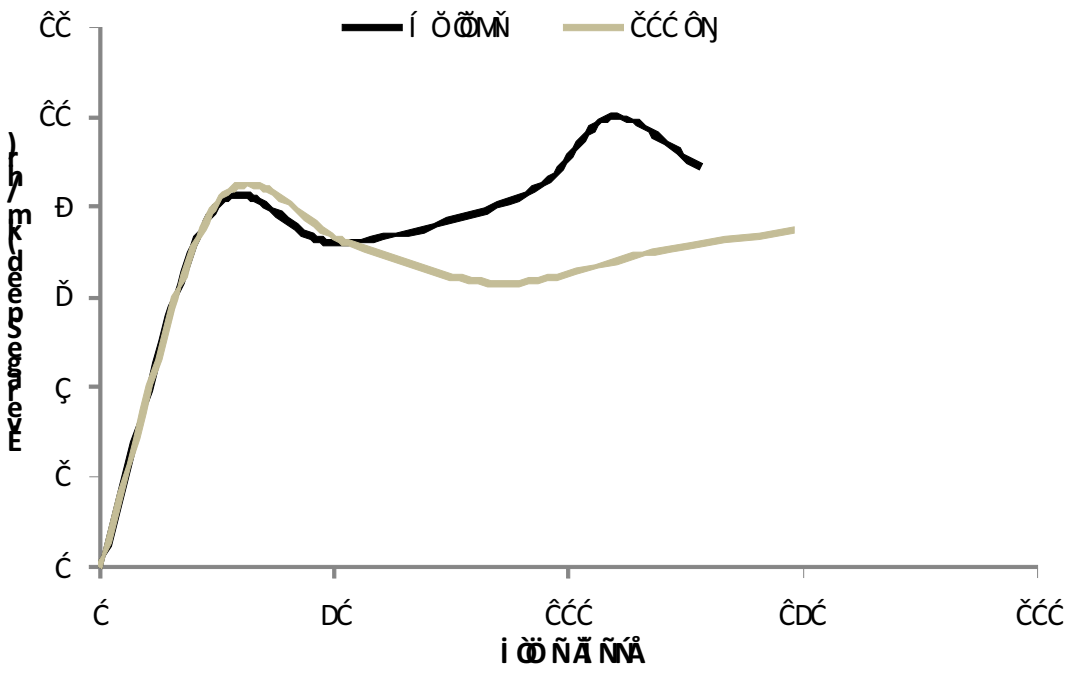

Figure 22: Average speed of FPD/CPD motorcycle trailer

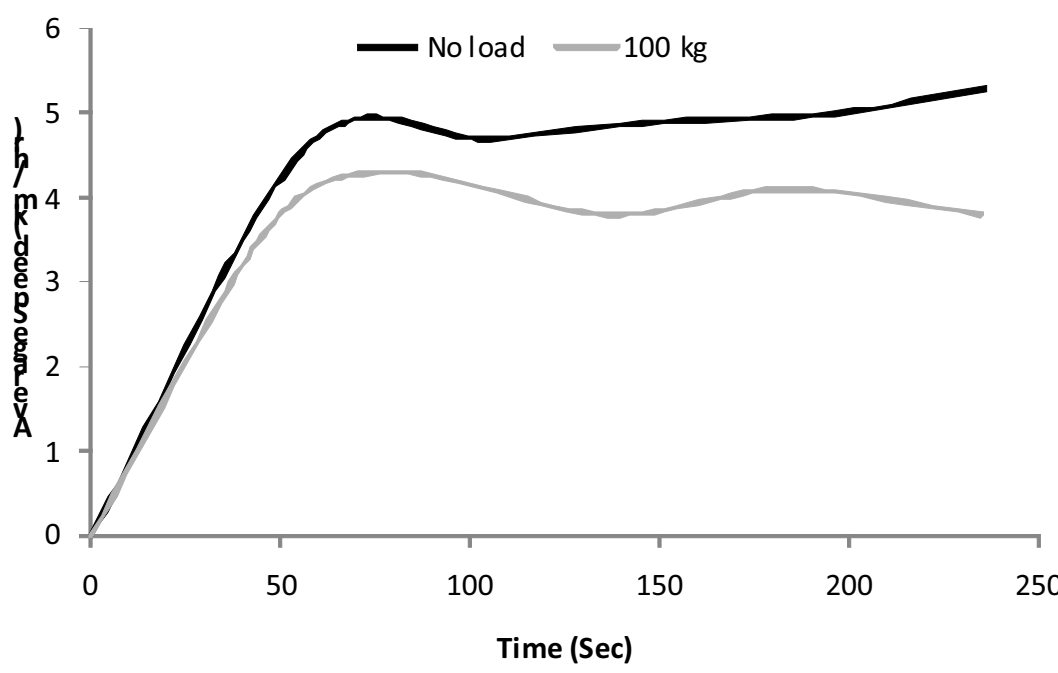

Figure 23: Average speed of FPD/CPD bicycle trailer

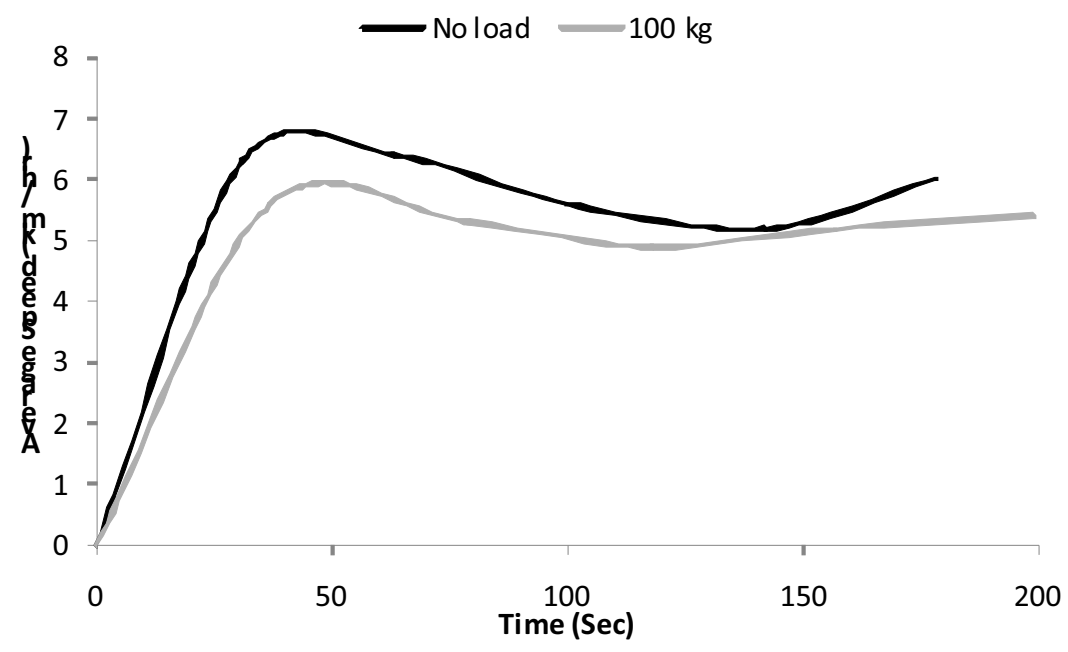

Figure 24: Average speed of WMD bicycle trailer 


\section{Conclusion}

This study has helped in safely increasing the load carrying capacity of humans (from $10-20 \mathrm{~kg}$ to 200 $\mathrm{kg}$ ) on long distances; safely increasing the load carrying capacity of bicycles; ease of detaching hitch; simple hitch system; convertible trailer; carrying large loads without polluting the environment (in the case of bicycle trailers); reduced drudgery; enhanced/proper material handling; reducing percentage of material damaged during transit; etc. There is no doubt that a proper usage of the trailers presented in this study will boost the heath and wealth of farmers ar wealth of farmers and other rural dwellers.

\section{Acknowledgments}

The authors of this paper wish to thank the Tertiary Education Trust Fund for the sponsorship of this research work through the 2011/2012 - 2014 Merged Research Project Intervention Fund for Olabisi Onabanjo University, Ago- Iwoye, Nigeria (Grant No. OOU/IBR/005/2017).

\section{References}

Ajiboye, A. O. and Ayantoyinbo, B. B. (2009). Analysis of transportation and distribution problems of agricultural products marketing in sub-Saharan region: an application to kolanut. Journal of Technology, Entrepreneurship and Rural Development, 4(1):188-200.

Ajiboye, A. O. and Afolayan, O. (2009). The impact of transportation on agricultural production in a developing country: a case of kolanut ria. International Journal of Agricultural Economics and Rural Development, 2 (2):49-57.

Dinye, R. D. (2013). The significance and issues of motorcycle transport in the urban areas in northern Ghana. Scientific Journal of Review, 2 (10): 256-272.

Michael, A. (1986). The Design of Bicycle Trailers. Intermediate Technology Publications Ltd London, UK New Edition. Retrieved 15th February, 2016 Edition. Retrieved 15 h WD_40/JF/ 35/26-659.pd

Mohammed, S. (1997). The Cycle Trailer in Ghana: A reasonable but appropriate technology. African Technology Forum, 7(3). Retrieved 15th February, 2016 from: web.mit.edu/africantech/www/articles/cyc le.html

Odoki, J., Ahmed, F., Taylor, G. and Okello, S.(2008). Towards the main streaming of an approach to include social benefits within road appraisal: a case study from Uganda. Transport Papers TP-17, Transport Sector Board, World Bank, Washington DC, USA. Available at: h t t p s : // o p e n k n o w le d g e worldbank.org/handle/10986/17464

Oyesiku, O. O (2016). Transport and Logistics in Nigeria. Heimmann Publishers Ibadan. Nigeria.

Philpott, J. (1994). Women and non-motorised transport: connection in Africa between ransportation and economic development. Transportation Research Record, 1441:39-

Porter, G. (2002). Intermediate means of transport. A review paper with special reference to Ghana.http://r4d.dfid.gov.uk/PDF/Outputs R7575015.pdf

Porter, G., Blaufuss, K. and Acheampong, F. O. (2007). Youth, mobility and rural livelihoods in sub-Saharan Africa: perspectives from Ghana and Nigeria. Africa insight, 37(3):420-431.

Riley, A. and Bathiche, T.(2006).Poverty reductio and transportation infrastructure in TimorLeste. Report prepared for United States Agency for International Developmen (USAID) by Louis Berger, Washington DC, USA. $23 \mathrm{p}$. Available at: DCtp:/www/lowisberger.com/Insights/ at: dia/Files/LBC/PDF/Insigh//pritim//me

Riverson, J. and Carapetis, S.(1991). Intermediate means of transport in Sub-Saharan Africa: its potential for improving rural travel an transport. World Bank Technical Paper 161, African Technical Department Series. World Bank, Washington DC, USA

Stackey, P., Ellis, S., Hine, J. and Ternell, A. (2002).Improving rural mobility: Options for developing motorized and nonmotorized transport in rural areas. The nonmotoized transport in mulareas. The International Bank for Reconstruction and Development/ The World Bank.1818 Street, NW, Washington, DC 20433.

Starkey, P.(2002). Local transport solutions for rural development. Department for International Development (DFID),
London, UK.48p. ISBN 1861924275. Available at:

http://www.animaltraction.com/StarkeyPa pers/Starkey-Local-Transport-SolutionsA4 screen.pdf

Starkey, P., Tumbahangfe, A. and Sharma, S.(2013b).External review of the District Roads Support Programme (DRSP) Final Report. Swiss Agency for Development and Cooperation, Kathmandu, Nepal. 82p. http://drsp.squarespace.com/storage/DRS P-Review-FinalReport.pdf

Starkey, P (2007). Rural transport services in Africa: Lessons from rapid appraisal surveys in Burkina Faso, Cameroon, Tanzania and Zambia. SSATP Working Paper 87B Sub-Saharan Africa Transport Policy Program (SSATP), World Bank, Washington DC, USA. 126p. Available at: https://www.ssatp.org/sites/ssatp/files/pdf s/Topics/rural/additionalresources/SSATP WP87-B-Lessons-Appraisal-Surveys.pdf

Starkey, P. and Hine, J. (2014). Poverty and sustainable transport. How transport affects poor people with policy implications for poverty reduction. $A$ literature review.

https://sustainabledevelopment.un.org/con
tent/documents/1767Poverty $\% 20$ and $\% 20$ sustainable\%20transport.pdf

Tunde, A. M. and Adeniyi, E. E. (2012). Impact of road transport on agricultural development: a Nigerian example. Ethiopian Journal of Environmental Studies and Management, 5(3):232-238.

Yaro, M. A., Okon, A. E. and Bisong, D.B (2014).The impact of rural transportation on agricultural development in Boki Local Government Area, southern Nigeria. Journal of Management and Sustainability, 4(4); 125-133.

Wallrapp, C. and Faust, H. (2016). Bicycle Ambulances in rural Uganda: Analysis of factors influencing its usage. World Transport Policy and Practice. 14(2): 38 46.

Ayre, M.(1986). The design of bicycle trailer Intermediate Technology Publication Lto, UK. New Edition.

Hastings, C., Port, G., Sundberg, K and Coffin, R. (2016). Designing a bike trailer as an alternative for transportation and distribution of goods- An interactive qualifying project. Higher Ground Farm Sponsored program. 